Ssciendo Studia Anglica Posnaniensia 55s2 (2020): 303-316

doi: 10.2478/stap-2020-0015

\title{
ACADIAN LITERATURE IN THE 21ST CENTURY - BETWEEN TRADITION AND MODERNITY. CHRONIQUE D'UNE SORCIERE DE VENT AND PIERRE BLEU BY ANTONINE MAILLET
}

\author{
ANNA ŻURAWSKA ${ }^{1}$
}

\begin{abstract}
The aim of this article is to investigate the way in which tradition combines with modernity in Antonine Maillet's novels Chronique d'une sorcière de vent (1999) and Pierre Bleu (2006). Having discussed the position and role of Maillet's fiction in Acadian literature, and having presented the way this prose depends on local culture, language, and folklore, the author of the analysis focuses on the elements of the represented world which go beyond the national character of this literature and at the same time place it within contemporary world literature. At the thematic level, both novels deal with significant questions of time and memory, introducing a reflection on the concept of inheriting memory and re-presenting the past. Consequently, the novels reflect on the role and responsibility of the writer, who, as a character, constitutes a part of the represented world. In this context, writing appears as a weapon in the fight against time, death, and oblivion. At the level of composition, the analysis focuses on the novels' complex narration, its multiple levels, numerous voices, fragmentation, and eclecticism.
\end{abstract}

Keywords: Antonine Maillet; Acadian literature; Acadian folklore; time; memory; figure of the writer.

\section{Introduction}

In Aventuriers et sédentaires. Parcours du roman québécois, published in 2014, Lise Gauvin discusses the undefined status of Quebec literature and tries to find a suitable term for it (regional, peripheral, minor, postcolonial) which would reflect its position within world literature. According to the scholar, none of the definitions considered fully presents the specificity of the literature of Quebec,

1 Nicolaus Copernicus University in Toruń; ul. Bojarskiego 1, 87-100 Toruń, POLAND. zurawska@umk.pl 
and at the same time they pose a risk of marginalization. The difficulty is related not only to the francophone province of Canada but also results from the ambiguity characteristic of the very term "francophonie", and is thus applicable to francophone literatures in general. Gauvin asks the following question: "Comment, en effet, désigner les diverses littératures de langue française hors de France sans les marginaliser et, d'une certaine façon, exclure?" [How can the diverse literatures in the French language that are written outside France be defined without marginalizing them, or even in a certain way, excluding them?] (Gauvin 2014: 7-8).

While the literature of Quebec has a relatively well-established position both in Canadian literature and among francophone literatures, e.g., due to the developed, autonomous publishing system, tools that ensure its popularization (radio, television, publishing houses, universities, literary prizes, etc.) as well as support for Quebec writers, Acadian literature seems to occupy the periphery of not only Canadian, but also francophone and Quebec literature. This situation does not result from the quality of this writing or the often national, and thus quite hermetic nature of this writing, but from such factors as the relatively short history of the literature of this region, which does not exist as Acadia $^{2}$ on the world map, but which includes New Brunswick, New Scotland, and Prince Edward Island. Jean Morency compares Acadia to an archipelago extending over a vast territory (Morency 2006: 60); the scholar stresses that it is not a nation in a geographical sense, but rather a historical and cultural community with a strongly articulated identity, still related to the territorial affiliation ${ }^{3}$. For Claude Beausoleil, Acadia is a word denied by cartography but which is omnipresent at the affective level (Beausoleil 1999: 7-8). It is this affective attitude towards Acadia that is found in the writings of almost all Acadian writers.

\section{Antonine Maillet and Acadian literature}

The relatively short history of this literature does not mean that the origins of the nation, preceding the establishing of Quebec by Samuel de Champlain, had no founding myths or stories related to its later history - the deportation and return to the Maritime provinces. A good example may be the renowned Évangéline, an Acadian story par excellence, although written in English by the American poet Henry W. Longfellow. However, what should be stressed is the fact that this

2 Marguerite Maillet highlights the contribution of eminent Acadians (Antonine Maillet, Viola Léger, Rose-Marie Landry, Édith Butler, Jacques Savoie) to culture, and their international popularity, which does not result, however, in official recognition of the borders of Acadia (Maillet 1989: 15).

3 In the present article, the Acadian nation will therefore mainly refer to so-called Acadiens des Maritimes, and not to the diaspora (Acadiens de la diaspora). 
literature was predominantly oral. Robert Viau emphasizes that Acadia had been a country with practically no literature (Viau 2008: 312) until the first publications of Antonine Maillet in the second half of the 20th century, particularly the novels which brought her fame in Canada and abroad, i.e., $L a$ Sagouine (1971) and Pélagie-la-Charrette (1979). Maillet is the only Canadian writer in history to have won the Prix Goncourt for the latter, and thus recognition in the international arena. In a speech opening a conference on the reception of the works of Antonine Maillet which was held in 1988, Marguerite Maillet stated that "no historian, no patriot and no artist has contributed as much as she [Antonine Maillet] did to spreading knowledge about Acadia in Canada and abroad" (Maillet 1989: 14). The works of Antonine Maillet have not changed the peripheral status of Acadian literature completely, but gave it visibility and recognizability, mainly in the francophone area and in France itself ${ }^{4}$, as well as in English-speaking countries 5 . Moreover, Maillet has introduced the literature of Acadia into modernity. Raoul Boudreau claims that Acadian modernity began with the first publications of Antonine Maillet and Ronald Després, and has lasted to this day (cf. Boudreau 2006: 42). Denis Bourque calls Maillet the founder of contemporary Acadian literature (Bourque 2015: 63-64). The writer's merit is undoubtedly the ability to combine Acadian heritage with modernity; local folklore with the tradition of world literature; reflection on the national identity, and the economic and social inequality of the Acadians with a universal message. Robert Viau concludes that Antonine Maillet connects the old and the new order, as well as oral and written literature (Viau 2008: 325).

Along with the works of Antonine Maillet, the shift in Acadian literature was also caused by a change in the perception of the painful history of these people. In Maillet's works, persecution, suffering, or the negation of the Acadians' right to exist are not reasons for complaints, resentment, or resignation, but they constitute a starting point for a constructive and hopeful perception of the present and the future through the past (Maillet 2000: 197). Robert Viau notes that the writer creates a new Acadian mythology, replacing loss and absence with revival and hope. Maillet's dynamic heroine, Pélagie, thus replaces Longfellow's Évangéline, who functioned as a symbol of despair and resignation (Viau 2008: 318).

In this respect, Maillet is close to Proust, who, along with Rabelais, Shakespeare, Faulkner, and Márquez, is one of her literary masters. Transforming

4 On the reception of Maillet's works in France, Belgium, the US, Acadia, Ontario, and Quebec see Maillet \& Hamel (eds.) 1989.

5 Despite the difficulty related to the French Acadian language, some of her texts were translated into the English language i.a. La Sagouine (the first translation by Luis de Cespedes in 1979, the second by Wayne Grady in 2008), Pélagie - The Return to a Homeland (translated by Philip Stratford in 1982), Mariaangélas (translated by Ben Z. Shek in 1986). Cf. http://prixlitteraire.acadie.com/note.pdf. 
not only a personal but also a national tragedy into beauty, that is, into art, or Évangéline's pain into Pélagie's bravery, is one of aesthetic and ethical postulates presented in Maillet's works. The author once said in an interview: "Chacun de mes livres est sorti de la mort de quelqu'un ou d'une déchirure. J'ai perdu des amis. J'ai eu des déceptions. À chaque fois, j'en ai fait de la pâture à beauté, à transformation, à réincarnation" [Each of my books originated in somebody's death or split. I have lost friends. I have experienced disappointments. Each time, however, I regarded those experiences as a foundation for beauty, a motivation for a change and transformation] (Michaud 2000: 27). Proust's concept of literature as a beautiful lie (Proust 1892: 17), as a reality more true than the empirical perception of the world is also close to Maillet (Viau 2008: 21).

\section{Antonine Maillet and the 21st century}

Considering the fact that Maillet's writing career began at the end of the 1950s and has already been explored, for example, by the previously quoted Robert Viau in Antonine Maillet. 50 ans d'écriture (2008) ${ }^{6}$, which summarizes her literary output, an effort to analyze her works anew might seem superfluous, particularly in the context of this issue devoted to 21 st century Canadian literature. Another difficulty is the fact that her novels and theatrical plays constitute a certain whole, which Robert Viau calls after Balzac's The Human Comedy "an extensive Acadian human comedy" (Viau 2008: 323). The reader finds in subsequent works the same places, the same characters, the same already familiar imaginary world as if each of these texts was a chapter of a larger literary project. Her works are also called "Acadian mythology", "an epic", or simply "a saga", and are often compared to the construction of a cathedral (Viau 2008: 323). In this context, each novel should be analyzed in relation to the previous ones.

Regardless of the above, it seems interesting to study the latest works of Antonine Maillet, who is now over ninety years old, yet regularly publishes new

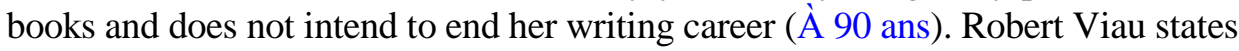
that in her recent novels, the writer introduces new themes and characters to the world already known to the reader (Viau 2008: 12), inspired by the changing contemporary world and the confrontation with passing and old age. Moreover, the novel Chronique d'une sorcière de vent (2000 [1999]), Chronicle of a Witch of the Wind), which apart from Pierre Bleu (2006) is the subject of this analysis, seems to express Maillet's full artistic talent also with regard to the text's narrative structure and the approach to time. While there are quite a few studies of her works from the second half of the 20th century, particularly of her best known texts $L a$ Sagouine and Pélagie-la-Charrette, the number of those concerning her latest

$6 \quad$ Also in Bottos 2000; Patterson 1983; Lord 2002. 
publications and the two aforementioned novels is limited ${ }^{7}$. Hence the following analysis, which aims to study the intertwining of tradition and modernity in Maillet's prose published at the beginning of the 21 st century, seems justified and may supplement, at least to some extent, the comprehensive critical work on her writing. The analysis focuses mainly on the role of the writer in the narration, the specificity of the narrative, and the approach to memory and time.

\section{Chronique d'une sorcière de vent and Pierre Bleu - characteristics}

The reason for choosing Chronique d'une sorcière de vent and Pierre Bleu is dictated by the visible similarity in constructing the universum in these novels, particularly in terms of spacetime, the Acadian community, and the protagonists. However, the stories differ in their narrative structure. As far as space is concerned, although it is named differently - in the first novel it is called Bouctouche (the village where Antonine Maillet was born) and in the second one, Grand-Petit Havre (Great-Small Haven) - in both cases it is the same idyllic place, a port village picturesquely located and surrounded by the sea, dunes, forests, and hills ${ }^{8}$. Its isolation favours the creation of an original micro-world with its own language and traditions. Robert Viau also stresses the fact that Bouctouche was named Grand-Petit Havre by the first inhabitants of these places: the Indian Micmac tribe (Viau 2008: 296). Despite the authenticity of the name, it is very poetic and symbolic in itself; Maillet thus points out on the one hand the modest origins and lives of the characters (petitesse), and on the other hand their rich imagination as well as determination in preserving identity and in fighting for a better future (grandeur). In Pierre Bleu, where the linear narrative covers the whole century starting from the late 19th century, Grand-Petit Havre undergoes an authentic transformation from a hamlet with several houses towards an industrialized, even urbanized place. Moreover, the two fictional settlements reflect a certain pattern characteristic of villages founded by French colonizers (also in Quebec), in the centers of which there were always a church, a presbytery, a doctor's house (and often also a lawyer's house), surrounded by other, more modest houses of the so-called Habitants, who farmed the land or, as in both novels, worked as fishermen. The process of building the church is an important theme in Pierre Bleu, and its fire appears as a leitmotiv in many of Maillet's works, including both of the analyzed novels.

The two books present the everyday life of the villagers, but in Pierre Bleu the emphasis is put on the development of the place and establishing new

See Brochu 2000, 2007; Merkle 2000.

This seems characteristic of the Acadian identity discourse which, as Skidds notes, is built upon emblematic geographical elements of the landscape (Skidds 2016: 59). 
institutions of education aimed at protecting Acadian culture. On the other hand, Chronique d'une sorcière de vent is a certain quest, the aim of which is reconstructing the turbulent love story of Carlagne and Yophie, living at the turn of the 20th century. However, what is more important in the novel than the narrative on love between the characters is the narrative on the act of storytelling. This aspect will be analyzed further in the article.

Both novels preserve the oral character of storytelling, which is achieved thanks to recreating the spoken Acadian language, introducing the character of a storyteller (Fr. conteur), and referring to Acadian legends or the so-called contes. In such narrative there is usually a pattern of a struggle between good and evil, consequently represented by a priest and some incarnation of the devil, because, as Maillet suggests, a monster is a necessary element of a good story (2000: 52). Thus, the interference of supernatural forces is not uncommon, and in Maillet's works creatures from the other world have a significant impact on the shape of the plot. However, the line between good and evil is not always obvious. The eponymous hero Pierre Bleu is a miraculous character, a giant with blue skin, born because of the confrontation between archangel Michael and Lucifer and thus combining the elements of good and evil. The hero who unexpectedly arrives in Grand-Petit Havre witnesses and participates in the lives of its residents for over a hundred years, using in various situations the antagonistic forces - good and evil - to satisfy the needs of the village. He is also a very positive character. By contrast, the role of the priest - like in the aforementioned contes - cannot be viewed in metaphysical categories or identified with spiritual guidance. He is usually a very resourceful character, an initiator of progress in the village, the one whose powers in the fight against evil forces are comparable to those of a shaman or a mage.

\section{A "beautiful story" and its creator}

What both of the novels illustrate are the words from Chronique d'une sorcière de vent: "un livre ne cherche pas à dire quelque chose. Il raconte, ça suffit. Il raconte ce qui est, a été, peut-être ce qui sera. Il raconte pour raconter, pour conter une belle histoire" [a book does not try to say something. It tells, and that is sufficient. It tells something that is, has been or perhaps will be. It tells to tell, to narrate a beautiful story] (Maillet 2000: 12). The frequency with which the verb "to tell [a story]" (Fr. raconter, conter) is used reveals a nostalgic approach to creating and listening to beautiful stories related to Acadian folklore, and thus to the past. Yet both novels are not limited to a mere recreation or recording of old legends, but testify to the possibility of the old order corresponding with modernity. The very act of storytelling is what Maillet reflects upon: in Chronique d'une sorcière de vent, she introduces the character of a writer, also 
named Maillet. The latter's role consists mostly in listening and writing down the story about Carlagne and Yophie told by various narrators. In turn, Pierre Bleu is an example of a linear structure of the tale, even though towards the end of the novel the character of a future writer, who will be responsible for writing down the history of Grand-Petit Havre, is introduced. As a result, the writers from both novels appear to be the same person, which is confirmed by their specific call to writing, jokingly presented through the scene when the star that falls off the Acadian flag sticks to the bottoms of future writers. The only thing that differentiates this flag from the French one is that star, which in the episode recalled in both novels (and other texts by Maillet) predestines the girl to have a unique fate.

In the context of the peripheral situation of Acadian literature, Raoul Boudreau states that such a device, i.e., the introduction of the figure of a writer into the text, is in some sense a demand to recognize the Acadian writings and the role of the writer within a literary institution and within the society in general (Boudreau 2006: 44). However, leaving the status of Acadian literature aside, the figure of a writer and the mise en abyme of the work itself (i.e., the representation of the process of its creation) is characteristic predominantly of modern literature. Yet in Chronique d'une sorcière de vent the fictional writer is not the one who validates the very act of writing; she instead puts herself in the position of a mindful listener, investigator, or ethnologist, who is only a tool for writing observations and the words she hears, as if the story itself, created by many people and communicated orally, was the ultimate value. It is an approach practiced by Maillet herself, who belonged to the generation that had the opportunity to listen to Acadian stories and legends told by authentic, traditional conteurs (Viau 2008: 325-326). The narration imitates a typical enunciative situation (Boudreau 2006: 43) with all its actors: enunciator and co-enunciator as well as storyteller and their audience. However, their roles are interchangeable: those who have been telling the stories become listeners, only to take again the role of narrators a moment later. Due to this interchangeability of the roles, each storyteller must adopt a humble and mindful attitude towards the story and its subsequent narrators. Numerous narrative voices on the one hand introduce intentional fragmentation of the story, thus making it incomplete, and, on the other hand, create a certain surplus achieved through additional information passed by subsequent narrators. The latter draw pleasure from telling the story; they extend the tale on purpose, constructing it from understatements and simulating lack of knowledge.

It should be specified, however, that the narrators are always female. In Chronique d'une sorcière de vent all the storytellers (Fr. conteuses) are old women, in most cases nuns. Although the choice to have a cloistered life confirms that the characters were assigned stereotypical roles - in the Acadian community of the past it was one of the few paths a woman could take to make a career and 
have access to education - thanks to the prestige of storytelling they are elevated to the position of an aoidos or a sage. There are a great number of references to Homer in the novel, and one of the narrators, Sister Diogène, is blind. All of them are very intelligent and clever in constructing the story. The protagonists of their tales are also women, usually distinctive, independent, enterprising, and intelligent. They are the ones who break different taboos (forbidden loves, samesex relations, Carlagne's androgynous looks, etc.) and are characterized by openness. They are also the guardians of memory and strive to preserve the Acadian identity. Considering the entire literary output of Maillet, Robert Viau notes that while women are distinguished by their strength of character and astuteness, men are only their pale reflections (Viau 2008: 315).

The multitude of participants in the enunciative situation also leads to the tale being broken off at the most interesting moments. This is, of course, a wellknown mechanism of suspense, of telling a story in a way that builds uncertainty and arouses the curiosity of the listener/reader. However, this mechanism simultaneously serves to represent a real situation of a meeting between conteurs and the audience, when people interrupt, go out, butt in, comment on the story and the way it is told, demonstrate tiredness, etc. ${ }^{9}$, thus disrupting the continuity of the story. In the context of the imitation of a real meeting and conversation, it is natural to use interjections such as chut!, ouf!, hé!, hm-hm, etc., which abound in the text, making it more dynamic and natural. These efforts to render orality in narrative conveys Maillet's conviction that a story written down in a book will never equal the beauty of oral transmission (Maillet 2000: 89, 141).

\section{Narration}

This approach, evoking the Acadian as well as Quebecois tradition of veillée de contes $^{10}$, reveals not only the need to write down the legend itself, but also to capture the conditions and atmosphere in which such a story was created and told. Clearly, this offers a chance to narrate at two levels: that of the frame story or extradiegetic narration (according to Genette's terminology), and that of intradiegetic narration. The first level refers to the very process of telling a story, gathering various accounts, searching for witnesses - and standard French is used

$9 \quad$ This type of narration, imitating the situation in which there is a storyteller and (a) constantly interrupting listener(s), had already been perfected in the 18th century by Denis Diderot in his Jacques the Fatalist, and with a significantly titled story Ceci n'est pas un conte (That is not a story).

10 Veillée de contes, literally "vigils around legends", are meetings whose purpose is to tell stories and listen to them. This used to be a form of entertainment or a way to pass long winter evenings. Today it is still an important tradition in Acadia and Quebec, practised, e.g., by Fred Pellerin, yet it is a folkloristic practice rather than an actual element of Acadian everyday life. 
here. The second, intradiegetic narration, is the actual story, describing the fates of Carlagne and Yophie; this level uses Acadian French with strongly marked features of spoken language (at the level of syntax, grammar, and lexis). Thanks to this narrative composition, the line between fiction and reality is blurred - both worlds, the fictional and the supposedly real, coexist. It also contributes to the interlacing of past and present, showing interconnections between these two temporal planes.

The first problem, the relation between fiction and reality, constantly reappears in Maillet's prose. For her, the lie of literature becomes closer to the truth than the reality from which the author would like to "emigrate": "Je devrai partir, m'exiler bien au-delà des frontières de mon pays. M'exiler du réel. Dans l'écriture" [I will have to leave, emigrate further than beyond the borders of my own country. Emigrate out of reality. Into writing] (Maillet 2000: 11-12). A reallife story-gathering trip from Montreal to New Brunswick is connected with the wish to voluntarily "emigrate" from reality into fiction. At the same time, the narrator notices that the octogenarian nun, Sister Domrémy, the dominant narrator recounting the fates of Carlagne and Yophie, "à l'ombre des quatre murs de son cloître [elle] a connu une vie plus riche que le plus aventurier des grands explorateurs" [in the shadow of the walls of her cloister had known a life more adventurous than many great explorers] (Maillet 2000: 25), thanks to the stories she had heard and told.

\section{Memory and time}

The two levels of narration also allow the author to approach time in a specific way, i.e., to create a dimension in which the past and the present coexist. The question of temporality is not only reflected by the narrative structure, but it is also an autonomous topic of Chronique d'une sorcière de vent ${ }^{11}$, introduced as early as on the first page of the prologue, in which the narrator declares her rejection of the linearity of time, postulating instead perceiving it as a sphere. With such an approach, different temporal planes can intersect at different points, so a distant past can have the same status as the present. The concept of a spherical temporal-spatial dimension is in turn represented in Pierre Bleu by a magical gyrating dance of the blue giant, during which time stops and the horizon line draws closer or further, shrinking or expanding the Acadian micro-world. In this novel, the aporia of time is represented by Bibiane-la-jeune - Maillet's porte-parole: Bibiane " $n$ 'arrive pas à suivre le professeur de philosophie pour qui le Temps était une question comme les

11 This topic returns in many other works of Maillet. Moreover, the first part of the title, chronique, not only suggests the form of a novel, but above all stresses the importance of time in the analysed work. A chronicle is in this context an inscription of the past, often fragmentary and incomplete. Still, the contemporary reader is able to decipher its meaning. 
autres, logique, définissable, avec sa réponse bien arrondie dans un paragraphe. Elle tournait la question dans tous les sens, et son esprit se troublait" [cannot follow the reasoning of the philosophy professor, for whom Time was a question like any other: logical, easy to define, with a polished answer contained in a single paragraph, while she kept turning this question in her mind this way or that, and it troubled her spirit] (Maillet 2006: 254). Perhaps this is why it is necessary to have metaphors, personification of memory, symbolic representations, and time extended into a multi-generational saga, similar to Márquez's One Hundred Years of Solitude, in order to capture time, understand it, or stop its devastating flow (Maillet 2006: 265). The return to the past also echoes the concept of a Proustian "search for lost time". However, the writer emphasizes the role of memory reaching beyond the boundaries of her own life, hidden in genetic memory (Michaud 2000: 21-22). Maillet attempts to make that past present. This has specific consequences for the perception of the writer's role and the shape of the novel's universe. According to Maillet, "Le rôle de l'écrivain, c'est de se souvenir d'expériences immémoriales, dont on ne se souvient pas. Ainsi, on recrée le monde" [the role of the writer is to remember past events which we have forgotten. In this way we recreate the world] (Michaud 2000: 22). A writer should explore memory, both individual and collective. Thus, Maillet finds it easy to identify with humanity's heritage, even the most distant. In an interview published in La voie du cour, Maillet claims to be a contemporary of Sophocles, Aristotle, and Caesar (Michaud 2000: 23). Hence, intertextuality (very broad in geographical and temporal terms) is important in Maillet's works as it allows the writer to include Acadian folklore in Western culture (e.g., Carlagne and Yophie are compared to Tristan and Isolde, and the eponymous character in Pierre Bleu is modelled on Gargantua and Pantagruel). In the writer's view, Acadians are "un peuple de belles histoires, avec un goût prononcé pour l'épopée" [a people of beautiful stories, with a particular passion for epics], which they share with ancient Greeks (Maillet 2000: 52).

Like an orally transmitted story, an intertextual dialogue carries an inherent notion of transmission, processing, and searching for new meanings. At the same time, intertextual references make it possible to build a community based on words that can be shared. This is presented by the very title of the novel, containing the expression sorcière de vent (Witch of the Wind), which the first French settlers brought to Acadia from their homeland, and which simply means a tornado. In the novel, this name is given to Carlagne. The phrase itself, a reference to France and the beginnings of Acadia, is a testament of mingling cultures, the influence of the past on the present, and the weight carried by words. The notion of "transmission" seems to be particularly important in the novels with regard to the context of narration time. Chronique d'une sorcière de vent continuously emphasizes the time of the frame narration, located at the turn of the 21 st century, while a part of the storyline of Pierre Bleu takes place at the turn 
of the 20th century. The idea of moving from one era to other not only frightens the characters, but also gives them hope that new stories can be created upon the old ones. In Pierre Bleu, the timeline is linear but encompasses several generations experiencing different events. As the hump of the eponymous hero contains memories, he may be regarded both as a witness to the depicted events and, to a certain extent, the embodiment of the very memory.

Therefore, the word gives access to the past, as art can create or re-create what is gone. This creative power of literature, presented even more clearly in Maillet's novel Le Huitième jour, seems to be particularly important in the face of death, ubiquitous in Maillet's works. In Pierre Bleu the subsequent generations of the inhabitants of Grand-Petit Havre pass away (although this novel also gives voice to the dead, who in the cemetery comment on different events in the town). In turn, all the narrators of Chronique d'une sorcière de vent are nearly nonagenarians (as is the author), and some of them die before they finish the stories they have been telling. Maillet, the character who is trying to write down their memories in time, sums this up in the following way: "les seules archives qui m'intéressent ne se trouvent pas en bibliothèque, mais dans les quelques rares mémoires qui gardent encore précieusement les trésors d'un siècle" [for me, the only interesting archives are not in a library but in those few rare memories which still preciously guard the treasures of the whole century] (Maillet 2000: 173). Thus, writing means wanting to save the old tales, the treasures of Acadian literature. What is more, writing is a fight against death and oblivion - of specific persons as well as of the entire Acadian culture. Maillet's writing is therefore to have a mythogenic power. However, this fight is not dramatic or hopeless; on the contrary, it is motivated by gratitude for other people's lives, the love for life or even its glorification, and by the desire to immortalize characters and events, as suggested by the ending of Pierre Bleu (Maillet 2006: 279).

Besides collective memory, individual memory is also important. The adult Maillet, the narrator, is accompanied by a girl, Radi, her childlike alter ego, with whom she enters into an internal dialogue. This is clearly signalled as early as on the first page of the novel: "Donne-moi la main, Radi, toi, mon double, ma mémoire, mon histoire primaire et primitive, l'enfant que je fus, souffle-moi dans les narines comme Dieu au grand-père Adam, ramène-moi au temps où tout a commencé pour nous" [Give me your hand, Radi, my double, my memory, my first and primal history, the child I used to be, breathe into my nostrils [life] as God did to our forefather Adam, take me to the times when it all began] (Maillet 2000: 9). Also, Pierre Bleu opens with a scene in which a girl named Bibiane meets the eponymous hero. As in her previous works ${ }^{12}$, Maillet explores the

12 Radi first appears in On a mangé la dune (1962) and returns in later novels, e.g,. Le temps me dure (2003). 
world of her own childhood. The child waiting for new stories or, like Bibiane, wanting to hear the same story over and over again, to a certain extent justifies the revival of Acadian legends.

\section{Conclusion}

The aim of this article has been to investigate how Maillet's prose combines tradition with modernity, especially her two novels from the early 21 st century. Each novel may be regarded as yet another venture into the mythical world of Acadia, which has been created by the writer from the beginning of her career. Maillet's aim is to protect and record the literature that has been orally transmitted by the Acadians for centuries, even though their country has never been marked on maps. However, the writer's role is not limited to recreating and writing down Acadian legends: she creatively transforms them. The old traditions, customs and language in her writing gain a fresh vitality. Still, the reception of literature focusing on the matters of a minority often forgotten even in Canada (Maillet 1989: 14-15) would be limited to a narrow group of interested recipients if it did not go beyond national issues and local folklore. Thus, at the thematic level, the analysed novels deal with important questions of time and memory. Perhaps they cannot be approached according to the criteria of the post-memory theory, characteristic of modern literature (particularly as the writer identifies more with the Proustian concept of time and involuntary memory), but the notion of inheriting memory and the general theme of (re)presentation of the past are omnipresent in Maillet's fiction, as is the idea that a writer bears responsibility for recording that memory. Writing itself appears as a weapon in the fight against time, death and oblivion.

Other topics that are not thoroughly explored in this analysis but constitute an important subject of reflection for Maillet and other contemporary writers (also Quebecois) include the question of identity and being open for otherness; of freedom (which is one of the main themes in Pierre Bleu); of social inequality and economic discrimination ${ }^{13}$. Another significant issue is the role of education, which simultaneously opens hermetic communities to the world and provides them with tools for protecting and recording their heritage. As in Maillet's prose, it is predominantly women who are responsible for the education of the Acadian community, an aspect which, because of lack of space, has been only briefly discussed in this study. An interesting element is also Maillet's approach to narration: it is multi-level and fragmented, digressive and somewhat eclectic as it

13 In Maillet's prose, the communities in Acadian villages are usually very clearly divided into en haut, i.e., rich, anglophone entrepreneurs, and en bas, i.e., francophone Acadians, poor simple people. 
employs within one text different types of speech: witnesses' accounts, introspection (internal dialogue), a story-legend, etc. Interestingly, it is the figure of the writer that gives unity to this fragmented structure. Robert Viau concludes by saying that Maillet "inscrit l'Acadie dans l'espace même de la création littéraire" [has inscribed Acadia into the space of literary creation] (Viau 2008: 326). In turn, Daniel-Henri Pageaux refers to Maillet's fictional project as the Ithaca complex, which implies transforming one's corner of the earth into the metaphor of all places, i.e., showing the universal through the local (Pageaux 2000: 11). By contrast, Raoul Boudreau subversively concludes that Maillet does not make an Acadian a citizen of the world but turns the world into a huge Acadian territory (Boudreau, quoted in Viau 2008: 326). Despite all her attachment to Acadia, Maillet once stated: "Mais encore plus qu'à l'Acadie, je suis liée à mon siècle, à mon temps, à ma civilisation gréco-latine. Je suis liée à la beauté de la Création..." [Yet more than with Acadia, I have ties with my times, with my Greek-Latin civilization. I am connected with the beauty of Creation...] (Michaud 2000: 27). These words may contain the key to understanding the beauty of the world described by the writer, which in its Acadianness is simply an expression of wonderment at the world in general.

\section{REFERENCES}

Beausoleil, Claude. 1999. La poésie d'Acadie: Une tradition de modernité. In Gérald Leblanc \& Claude Beausoleil (eds), La Poésie acadienne. Les Éditions Perce-Neige, Les Écrits des Forges. 7-16.

Bottos, Katia. 2000. Antonine Maillet, conteuse de l'Acadie ou l'encre de l'aède. L'Harmattan.

Boudreau, Raoul. 2006. La littérature acadienne face au Québec et à la France. In Madeleine Frédéric \& Serge Jaumain (eds), Regards croisés sur l'histoire et la littérature acadienne. Peter Lang. 33-46.

Bourque, Denis. 2015. Antonine Maillet: Fondatrice de la littérature acadienne contemporaine. La Francophonie dans les Amériques 174. 63-64.

Brochu, André. 2000. Carlagne, Yophie, Almazar et le voyageur. Lettres québécoise 99. 17-18.

Brochu, André. 2007. L'Acadie à vol d'ange. Lettres québécoises 127. 19.

Gauvin, Lise. 2014. Aventuriers et sédentaires. Parcours du roman québécois. TYPO.

Lord, Marie-Linda. 2002. Territorialité et identité dans l'œuvre romanesque d'Antonine Maillet et de David Adams Richards. Francophonies d'Amériques 14. 117-130. DOI: 10.7202/1005188ar

Maillet, Antonine. 1986. Le huitième jour. Leméac.

Maillet, Antonine. 2000 [1999]. Chronique d'une sorcière de vent. Grasset.

Maillet, Antonine. 2006. Pierre Bleu. Leméac \& Actes Sud.

Maillet, Marguerite. 1989. Allocution d'ouverture. In Marguerite Maillet \& Judith Hamel (eds), La réception des æuvres d'Antonine Maillet. Chaire d'études acadiennes. 13-18. 
Maillet, Marguerite \& Judith Hamel (eds). 1989. La réception des æeuvres d'Antonine Maillet. Chaire d'études acadiennes.

Merkle, Denise. 2000. Maillet, Chronique d'une sorcière de vent. Études francophones 15(2). 265272.

Michaud, Marie-Andrée. 2000. La voie du cœur. Entretiens sur le cheminement intérieur avec Antonine Maillet, Andrée Ruffo, Jean Vanier, Yehudi Menuhin et plusieurs autres. Fides.

Morency, Jean. 2006. Les visages multiples de l'américanité en Acadie. In Madeleine Frédéric \& Serge Jaumain (eds), Regards croisés sur l'histoire et la littérature acadienne. Peter Lang. 55-66.

Pageaux, Daniel-Henri. 2000. Préface. In Katia Bottos, Antonine Maillet, conteuse de l'Acadie ou l'encre de l'aède. L'Harmattan. 5-14.

Patterson, John F. 1983. Antonine Maillet, traduite ou trahie? Meta. Journal des traducteurs 28(4). 352-357. DOI: 10.7202/003798ar

Proust, Marcel. 1892 (March). Un conte de Noël. Les petits souliers par M. Louis Ganderax. Le Banquet. 17. https://gallica.bnf.fr/ark:/12148/bpt6k32438v/f19.item (Accessed 12/02/2020.)

Skidds, Catherine. 2016. Réconciliation "espace" et "humain": Une lecture géocritique du roman Pas pire de France Daigle. In Cécilia W. Francis \& Robert Viau (eds), Littérature acadienne du $21^{e}$ siècle. Essais Perce-Neige. 59-73.

Viau, Robert. 2008. Antonine Maillet. 50 ans d'écriture. Les Éditions David.

Viau, Robert. 2016. Pour une littérature voyageuse acadienne. In Cécilia W. Francis \& Robert Viau (eds), Littérature acadienne du $21^{e}$ siècle. Essais Perce-Neige. 195-209.

Notes biographiques d'Antonine Maillet. http://prixlitteraire.acadie.com/note.pdf (Accessed 12/02/2020.)

À 90 ans, Antonine Maillet est loin d'avoir écrit son dernier mot. https://ici.radiocanada.ca/nouvelle/1169150/antonine-maillet-90-ans-ecrivaine-acadienne-sagouine (Accessed 12/02/2020.) 